\title{
The Use of Medicinal Mushroom or Herb as Effective Immunomodulatory Agent
}

\begin{abstract}
Background: Medicinal mushrooms are mushrooms used with the aim for health enhancement. They have been used in traditional Chinese medicine (TCM) for thousands of years. These mushrooms and some herbal medicines have gain in popularity in recent times, largely due to a growing number of scientific studies that suggest their potential medical benefits. They are found to exert immunomodulatory effects through changes in the quantity of some specific cytokines in blood; as well as numbers and activities of distinct immune cell subsets. This article summarizes the immunomodulatory effects of two commonly consumed medicinal mushrooms (Coriolus versicolor and Ganoderma lucidum) and also three herbal medicines that have been categorized as immunomodulatory in function (Cordyceps sinensis, Astragalus membranaceus and Eleutherococcus senticosus).
\end{abstract}

Methods: A systematic search of published articles of clinical trial studies between 1985 and August 2015 was conducted in four electronic databases (EMBASE, PubMed, Scopus and Web of Science). The outcome measures included changes in the serum cytokines secretion and the number and functional activity of different immune cell populations.

Results: After a thorough literature searching of 237 relevant articles, 15 were included. Coriolus versicolor and Ganoderma lucidum showed immunomodulatory effects in both innate and adaptive immunity arms. There are only very few studies in each mushroom or herb, and unequivocal conclusions cannot be drawn. Future larger trials of randomized and placebo controlled clinical studies with laboratory investigation of changes of multiple immune populations and their subsets are needed in consistent with an evidence-based medicine approach.

Keywords: Medicinal mushroom; TCM; NK cells; Dendritic cells; Cytokines; Coriolus; Ganoderma

\section{James $\mathrm{Ng} \mathrm{W}^{1}$, William Cho $\mathrm{C}^{2}$ and Daniel Sze $\mathrm{MY}^{3}$}

1 Department of Health Technology and Informatics, The Hong Kong Polytechnic University, Hong Kong, China

2 Department of Clinical Oncology, Queen Elizabeth Hospital, Hong Kong, China

3 School of Health and Biomedical Sciences and Health Innovations Research Institute, RMIT University, Melbourne, Australia

Corresponding author: Daniel Sze MY

$\equiv$ daniel.sze@rmit.edu.au

School of Health and Biomedical Sciences and Health Innovations Research Institute, RMIT University, Melbourne, Australia.

Citation: James Ng W, Cho WC, Sze D MY. The Use of Medicinal Mushroom or Herb as Effective Immunomodulatory Agent. Herb Med. 2016, 2:1.

Received: January 09, 2016; Accepted: January 29, 2016; Published: Janaury 30, 2016

\section{Introduction}

The clinical application of single synthetic or highly purified pharmaceutical compounds for health and disease is the mainstream of Western medical practice. Pure compound offers the advantage of clear structure-function relationship of pharmaceutical activity and related potential toxicity. On the contrary, many herbal medicines contain mixtures of naturally derived compounds that the underlying clinically relevant chemicals are basically unknown, nor the related mechanisms of action and target cells.

Traditional Chinese medicine (TCM) herbs have been used for more than thousands of years in historical record among China, Japan, Korea and other Asian countries. TCM has been used for augmenting the immune status for healthy people and also as adjunct with cancer treatment (surgery, radiotherapy and or chemotherapy) for cancer patients [1]. Although TCM has been advocated for its relatively safe and potential clinical beneficial effects as in many individual cases, most evidence in the literature is predominantly that of the in vitro animal studies and laboratory experimental cellular models. In comparison, the published limited in vivo clinical studies are normally of small patient numbers, equivocal explanation of the randomization protocols and lack of placebo controls. 
There is a recent trend of studying TCM in the awareness of the concepts of "multi-directional" and "network" in the context of evidence-based medicine. An important advancement is the understanding that clinically useful medicine including western pure compounds may not be restricted to the "single compound single target" theory. It is clear now that even a single compound such as Thalidomide [2] produces its surprising significant clinical effects to extend Myeloma patients' overall survival by modulating diverse immunological cell populations. This multi-directional mechanism of action is also seen in a TCM compound of Arsenic Trioxide that exerts its clinical effects through interacting with multiple cells in particular through a few important immune populations [3]. A network pharmacology approach strategy has also been purposed to approach the investigation of the effects due to the TCM usage [4]. It is therefore logical to propose that TCM herbs, each of multiple chemical compounds, can exert their effects in multiple target cells such as the diverse immunological important populations and bring about the desirable clinical effects.

Medicinal mushrooms are defined as mushrooms used as medicinal agents. Specific immunotherapeutic properties have been characterized by more than 270 recognized mushrooms species [5]. In this review, the two medicinal mushrooms were selected because of their reported immunological activities in the management of chronic diseases including cancer [6], diabetes [7], heart disease, and other disorders [8].

One of the bioactive ingredients in medicinal mushroom that relate to the multi-directional immunomodulation is now known to be "Beta-glucan". Beta-glucans are polysaccharides found in mushrooms that are known as "biological response modifiers" because of their ability to activate the immune system [9]. It has been documented that bioactive polysaccharides or polysaccharide-protein complexes from medicinal mushrooms enhance innate and cell-mediated immune responses and exhibit antitumor activities in humans [10]. Several of the mushroom polysaccharide compounds have been preceded through phases I, II, and III clinical trials and are currently used extensively in Asia to treat various cancers and other diseases [11].

This review aims to examine the evidence of the clinical trials of two medicinal mushrooms namely Coriolus versicolor and Ganoderma lucidum. The focus is how these medicinal mushrooms affect various immunological populations. Results of three selected TCM herbs that are commonly used in cancer management for immunoregulation have also been tabulated in this review for comparison. These herbs are Cordyceps sinensis, Astragalus membranaceus, and Eleutherococcus senticosus.

\section{Searching strategy of literature databases}

The methodology searching was based on published articles between 1985 and August 2015 that were listed in the following electronic databases: EMBASE, PubMed, Scopus, and Web of Science. The English keywords for searching included: "Medicinal mushrooms"; "Traditional Chinese medicine"; "TCM"; "immunomodulation"; "cancer"; "carcinoma"; "tumor"; "Ganoderma lucidum"; "Coriolus versicolor"; "Trametes versicolor"; "Cordyceps sinensis"; "Astragalus membranaceus";
"Eleuther ococcus senticosus"; "Siberian ginseng"; "dendritic cell"; "NK cell"; "natural killer cell" and "cytokine". There was no other special limitation. In addition, the reference lists of recent reviews related to the search terms are examined.

Flowchart Figure 1 represents the searching strategy of the review. Abstracts and titles were initially screened for the relevant area and followed by full reading of the text. Selection of the final 15 articles were based on the following four inclusion criteria: (1) published as English language articles; (2) provided with full text details; (3) published as clinical trial studies; (4) the outcome measurement involved immune cells and or related products, such as natural killer (NK) cells, T cells, B cells and/or cytokine. Animal studies and in vitro studies were excluded.

\section{Results and Discussion}

After a thorough searching of the literature with an initial 237 relevant articles, 222 studies were excluded with final 15 articles [12-26] on clinical trial being selected. The measurements of the cytokine profile and immune cell subsets data from these papers were tabulated and discussed in Table 1.

\section{Coriolus versicolor}

Medicinal mushroom Coriolus versicolor also known as Trametes versicolor is classified as Basidiomycetes macrofungi class consisting of over 22,000 species. It is called "Yun Zhi" in China meaning of "cloud-like-mushroom". Its record of application in China can be traced back to The Compendium of Materia Medica written by Li Shizhen during the Ming Dynasty with over 120

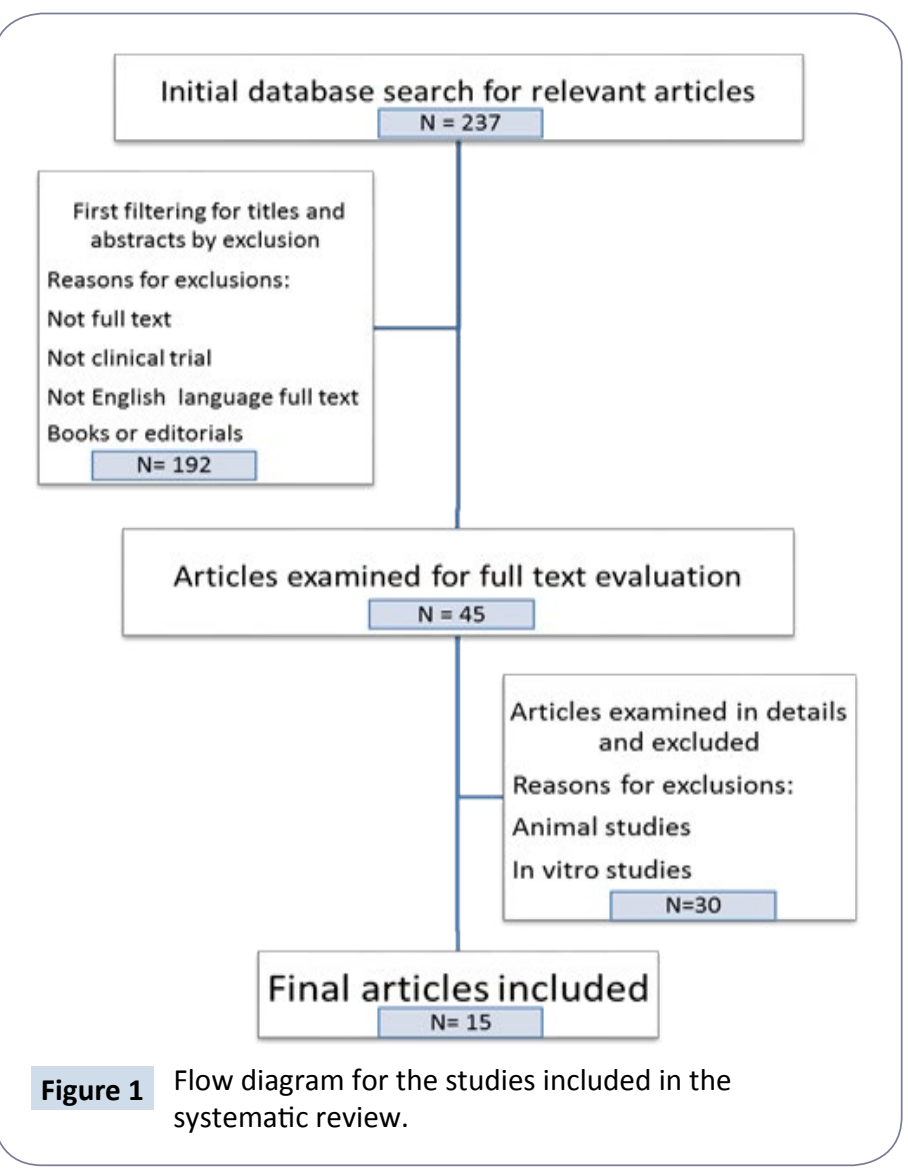

This article is available in: http://herbal-medicine.imedpub.com/archive.php 
Table 1 Effect of medicinal mushrooms or herbs on selected clinical trials.

\begin{tabular}{|c|c|c|c|c|c|}
\hline Mushrooms & Types & Dose/Treatment & Findings & Model & References \\
\hline $\begin{array}{l}\text { (I) } 1 . \text { Coriolus } \\
\text { versicolor }\end{array}$ & $\begin{array}{l}\text { PSK (polysaccharide- } \\
\text { krestin, protein-bound } \\
\text { polysaccharide) }\end{array}$ & $\begin{array}{l}\text { Randomized into a } \\
\text { control group ( } n=15 \text { ) } \\
\text { and a PSK group } \\
\text { ( } n=15 \text { ) } \\
\text { Randomly assigned } \\
\text { to } 2 \text { weeks' } \\
\text { chemoradiotherapy } \\
\text { CRT and } 4 \text { weeks' } \\
\text { S-1 administration } \\
\text { before surgery } \\
\text { (control group), } \\
\text { or the same CRT } \\
\text { with } 4 \text { weeks' PSK } \\
\text { administration (PSK } \\
\text { group) } \\
\text { Control group, take } \\
\text { oral S-1 } 80 \text { mg/m²/ } \\
\text { day divided into } 2 \\
\text { daily doses } \\
\text { PSK group,same dose } \\
\text { of S- } 1 \text { together with } \\
\text { PSK } 3 \text { g/day divided } \\
\text { into } 3 \text { daily doses, for } \\
4 \text { weeks }\end{array}$ & $\begin{array}{l}\text { A Cytokines - NA } \\
\text { B Cell subset - significant } \\
\text { increase ( } p=0.003 \text { ) of NK } \\
\text { cell by } 5 \% \text { in the peripheral } \\
\text { blood and } \\
\text { cytotoxic T cell counts } \\
\text { significant increase } \\
(p=0.005) \text { by } 153 \% \text { in peri- } \\
\text { tumour } \\
\text { significant increase } \\
(p=0.003) \text { by } 151 \% \text { in normal } \\
\text { mucosa }\end{array}$ & $\begin{array}{l}\text { Adenocarcinoma } \\
\text { of middle or } \\
\text { lower rectum } \\
\text { (CT3/CT4) } \\
\text { patients (30 } \\
\text { patients) }\end{array}$ & [13] \\
\hline 2. Coriolus versicolor & $\begin{array}{l}\text { PSK (polysaccharide- } \\
\text { krestin) }\end{array}$ & $\begin{array}{l}\text { Patients were } \\
\text { randomly assigned } \\
\text { to receive either } \\
3 \text { g PSK plus } 300 \\
\text { mg tegafur/uracil } \\
\text { (UFT): (PSK group) } \\
\text { or } 300 \text { mg UFT alone } \\
\text { (control) orally each } \\
\text { day for } 3 \text { months } \\
\text { and then for immune } \\
\text { status assessment } \\
10 \text { patients were } \\
\text { allocated to the PSK } \\
\text { group and } 11 \text { to the } \\
\text { control group }\end{array}$ & 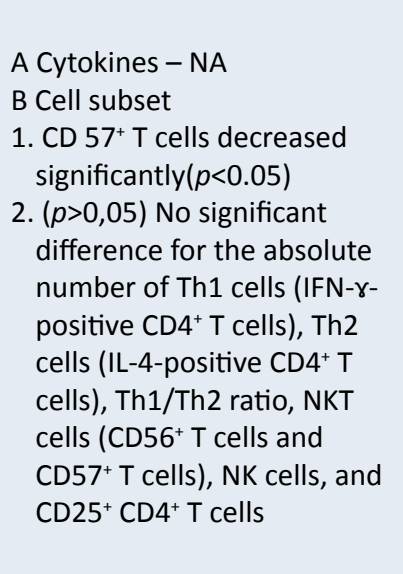 & $\begin{array}{l}\text { Stage III gastric } \\
\text { cancer patients } \\
\text { (21 patients) }\end{array}$ & [14] \\
\hline $\begin{array}{l}\text { 3. Trametes } \\
\text { versicolor } \\
\text { (Coriolus } \\
\text { vesicolor) }\end{array}$ & $\begin{array}{l}\text { Trametes versicolor freeze- } \\
\text { dried mycelia powder }\end{array}$ & $\begin{array}{l}\text { Each capsule contained } \\
500 \mathrm{mg} \text { of product } \\
\text { Each cohort comprised } \\
\text { of } 3 \text { participants } \\
\text { given one of three } \\
\text { doses of Trametes } \\
\text { vesicolor ( } 3 \mathrm{~g}, 6 \mathrm{~g} \\
\text { or } 9 \mathrm{~g} \text { ) }\end{array}$ & $\begin{array}{l}\text { A Cytokines - NA } \\
\text { B Cell subset } \\
\text { 1. Increased lymphocyte } \\
\text { counts at } 6 \text { and } 9 \mathrm{~g} / \text { day and } \\
\text { ( } p<0.05) \\
\text { 2. Increased NK cell functional } \\
\text { activity at } 6 \mathrm{~g} / \text { day ( } p<0.05) \\
\text { 3. Dose-related increases in } \\
\text { CD8 } 8^{+} \text {cells and CD } 19^{+} B \\
\text { cells but not CD4 } \\
\text { CD16 cells or } 56^{+} N K \text { cells }(p<0.05)\end{array}$ & $\begin{array}{l}\text { Breast cancer } \\
\text { women (11 } \\
\text { participants } \\
\text { recruited and } \\
9 \text { women } \\
\text { completed } \\
\text { study) }\end{array}$ & [15] \\
\hline
\end{tabular}




\begin{tabular}{|c|c|c|c|c|c|}
\hline $\begin{array}{l}\text { (II) } 1 \text { Ganoderma } \\
\text { lucidum }\end{array}$ & Ganopoly (polysaccharide) & $\begin{array}{l}\text { 1,800 mg Ganopoly, } \\
3 \text { times daily orally } \\
\text { before meals for } 12 \\
\text { weeks compared } \\
\text { with baseline } \\
\text { Total dose of Ganopoly } \\
\text { per day ( } 5,400 \\
\mathrm{mg}=270 \mathrm{~g} \text { fruiting } \\
\text { body of Ganoderma } \\
\text { lucidum) }\end{array}$ & 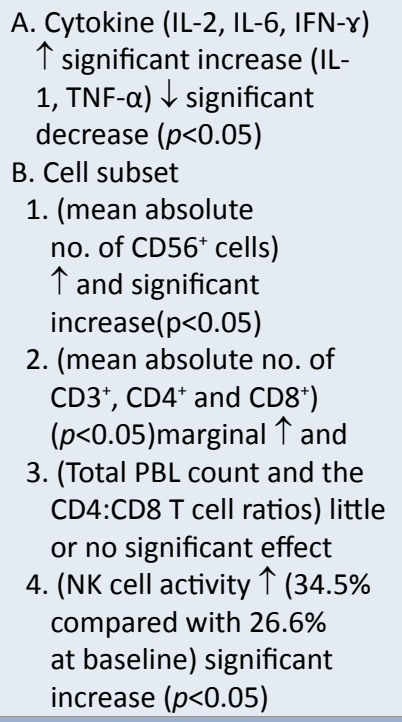 & $\begin{array}{l}\text { Advanced-stage } \\
\text { cancer patients } \\
\text { (with cancer } \\
\text { origin from } \\
\text { lung, colon, } \\
\text { breast, liver, } \\
\text { prostate, } \\
\text { bladder, brain } \\
\text { and unknown) } \\
\text { (34 patients } \\
\text { included but } \\
\text { only } 30 \text { patients } \\
\text { assessed } \\
\text { for immune } \\
\text { function after } \\
12 \text { weeks) }\end{array}$ & [16] \\
\hline $\begin{array}{l}2 \text { Ganoderma } \\
\text { lucidum }\end{array}$ & $\begin{array}{l}\text { Ganoderma lucidum } \\
\text { polysaccharides Ganopoly }\end{array}$ & $\begin{array}{l}\text { A randomized, } \\
\text { double-blind, } \\
\text { placebo-controlled, } \\
\text { multicenter clinical } \\
\text { trial. } \\
12 \text { weeks of treatment } \\
\text { with oral Ganopoly } \\
\text { or placebo at a dose } \\
\text { of } 3 \text { capsules ( } 600 \\
\text { mg } \times 3=1,800 \mathrm{mg} \text { ) } \\
3 \text { times daily before } \\
\text { meal. } \\
\text { A capsule of } \\
\text { Ganopoly (150 mg } \\
\text { polysaccharides) }=30 \\
\text { g fruiting body of } \\
\text { Ganoderma lucidum } \\
\text { or total dose of } \\
5,400 \text { mg/day of } \\
\text { Ganopoly=270 g/day } \\
\text { fruiting body. }\end{array}$ & $\begin{array}{l}\text { A. Cytokine - NA } \\
\text { B. Cell subset } \\
\text { 1. (Lymphocyte mitogenic } \\
\text { reactivity to concanavalin } \\
\text { A significant increase) } \uparrow \\
\text { 2. CD3 \% significant increase } \\
\text { and } \uparrow \\
\text { 3. NK cell activity significant } \\
\text { increase } \uparrow \text { and } \\
\text { 4. CD4 \% and CD4:CD8 ratio } \\
\text { marginal increase } \uparrow \text { and } \\
\text { 5. CD8 marginal reduction } \\
\downarrow \text { and }\end{array}$ & $\begin{array}{l}\text { Advanced-stage } \\
\text { (stage III to IV) } \\
\text { lung cancer } \\
\text { patients (68 } \\
\text { cancer patients } \\
\text { recruited and } \\
\text { only } 32 \text { patients } \\
\text { assessable) }\end{array}$ & [17] \\
\hline $\begin{array}{l}3 \text { Ganoderma } \\
\text { lucidum }\end{array}$ & Ganoderma lucidum extract & $\begin{array}{l}\text { Double-blinded, } \\
\text { placebo-controlled, } \\
\text { cross-over } \\
\text { intervention } \\
\text { study for } 4 \text { weeks } \\
\text { supplement with } \\
\text { encapsulated } \\
\text { Ganoderma lucidum } \\
\text { preparation (1.44 } \\
\text { g/day Ganoderma } \\
\text { lucidum; equivalent } \\
\text { to } 13.2 \text { g/day fresh } \\
\text { mushroom per day). }\end{array}$ & $\begin{array}{l}\text { A. Cytokines-Not done } \\
\text { B. Cell subset (CD4:CD8 ratio) } \\
\text { no statistical significant } \\
\text { change }\end{array}$ & $\begin{array}{l}\text { Healthy human } \\
\text { subjects (18 } \\
\text { healthy adults } \\
\text { aged } 22-52 \\
\text { years) }\end{array}$ & [12] \\
\hline
\end{tabular}




\section{Ganoderma lucidum}

\section{Ganoderma} lucidum
6 Ganoderma lucidum capsules

\section{Water-soluble Ganoderma lucidum polysaccharides}

Ganoderma lucidum extract contained $1.89 \%$ of terpenoids and $15.8 \%$ of polysaccharides
A non-randomized open-labeled study.

$1,800 \mathrm{mg} 3$ times daily $=5.4 \mathrm{~g} /$ day orally before meals for 12 weeks.

Each capsule contained $600 \mathrm{mg}$ crude extract of Ganoderma lucidum, with $25 \%$ (w/w) crude polysaccharides.

Total dose of Ganoderma lucidum per day $(5,400$ $\mathrm{mg})=81 \mathrm{~g}$ fruiting body.

A double-blind randomized placebocontrolled trial

$2 \mathrm{~g}$ of the extract or placebo twice daily for 10 consecutive days

Oral doses of

Ganoderma lucidum extract or placebo (4 capsules each time)

\section{0 male football}

players were randomly assigned to 4 groups: control (living at sea level), LHTL1, LHTL2 and LHTL3. The three

The capsules (Green Valley Ganoderma lucidum capsule) contain total extract isolated from the fruiting body of Ganoderma lucidum (Leyss. ex Fr.) Karst. by boiling water and pure pores.

The ratio of total extract with spores is $70 \%: 20 \%$ in $\mathrm{G}$ lucidum capsules. The main active component is polysaccharides with a ratio of more than $10 \%$ for the capsules.

\section{A. Cytokines \\ IL-2, IL-6 and IFN- $\gamma$ \\ increased but no statistical significance whereas \\ IL-1 and TNF- $\alpha$ were \\ decreased but no statistical significance. \\ B. Cell subset \\ $\mathrm{CD} 3, \mathrm{CD} 4, \mathrm{CD} 8, \mathrm{CD} 56$ \\ Non-significant change \\ in the absolute number of \\ Advanced-stage \\ (Stage III to \\ IV) colorectal \\ cancer patients \\ (47 patients \\ enrolled with \\ 41 patients \\ assessable)}

lymphocytes and NK activity $(p>0.05)$

\section{A Cytokines-NA}

B Cell subset

1. No changes in CD4, CD8 and CD19

2. No significant change in $\mathrm{CD} 56^{+} \mathrm{NK}$ cell number

\section{Human Normal} subjects (16 volunteers with 8 males and 8 non-pregnant females)
LHTL groups had stayed in normobaric hypoxic rooms for 28 days. The four groups trained together at sea level. LHTL1, LHTL2 and LHTL3 groups were provided with placebo, Ganoderma lucidum.

10 capsules $=2.5 \mathrm{~g} /$ day and Ganoderma lucidum 20

capsules $=5.0 \mathrm{~g} /$ day, respectively, for 6 weeks ( 2 weeks baseline supplementation followed by 28 days of the treatment protocol).
A Cytokines - NA

B Cell subset

No significant difference in number of $T$ cells in different groups
Male football players (40 males assigned into 4 groups) 


\begin{tabular}{|c|c|c|c|c|c|}
\hline $\begin{array}{l}7 \text { Ganoderma } \\
\text { lucidum }\end{array}$ & $\begin{array}{l}\text { Spore powder including } \\
\text { polysaccharides, } \\
\text { triterpenoids, alkaloids, } \\
\text { enzymes, and proteins }\end{array}$ & $\begin{array}{l}\text { A randomized, placebo } \\
\text { controlled trial } \\
\text { Spore powder of } \\
\text { Ganoderma lucidum } \\
1,000 \mathrm{mg} 3 \text { times a } \\
\text { day for } 4 \text { weeks }\end{array}$ & $\begin{array}{l}\text { A. Cytokines } \\
\text { TNF- } \alpha \text { and IL- } 6 \text { were } \\
\text { significantly lower } \\
\text { Mean serum TNF- } \alpha \text { pre- } \\
\text { and post-treatment in } \\
\text { experimental group were } \\
128.70 \mathrm{pg} / \mathrm{mL} \text { and } 71.89 \\
\mathrm{pg} / \mathrm{mL} \\
\text { Mean serum IL- } 6 \text { pre- } \\
\text { and post-treatment in } \\
\text { experimental group were } \\
62.43 \mathrm{pg} / \mathrm{mL} \text { and } 37.62 \mathrm{pg} / \\
\mathrm{mL} \\
\text { B. Cell subset - NA }\end{array}$ & $\begin{array}{l}\text { Breast cancer } \\
\text { (stage I-IIIA) } \\
\text { patients } \\
\text { (48 cancer } \\
\text { patients) }\end{array}$ & \\
\hline $\begin{array}{l}\text { 8. Ganoderma } \\
\text { lucidum }\end{array}$ & & $\begin{array}{l}\text { A randomized, double- } \\
\text { blind, cross-over } \\
\text { trial with placebo- } \\
\text { controlled run-in and } \\
\text { cross-over periods. } \\
\text { Treatment of } 12 \text { weeks } \\
\text { each on Ganoderma } \\
\text { lucidum treatment or } \\
\text { placebo, } 2 \text { capsules } \\
\text { twice daily. } \\
\text { The dosage=1.44 } \\
\text { g Ganoderma } \\
\text { lucidum extract/ } \\
\text { day taken with } \\
\text { two capsules (each } \\
\text { capsule contains } 360 \\
\text { mg extract) twice } \\
\text { daily=13.2 g of the } \\
\text { fresh mushroom. }\end{array}$ & $\begin{array}{l}\text { A. Cytokines - NA } \\
\text { B. Cell subset } \\
\text { No significant difference on } \\
\text { B-lymphocytes and T helper } \\
\text { cell counts and percentages } \\
\text { for the treatment group. } \\
\text { Co }\end{array}$ & $\begin{array}{l}\text { Hypertension and } \\
\text { or dyslipidemia } \\
\text { patients ( } 26 \\
\text { patients } \\
\text { recruited } \\
\text { with final } 23 \\
\text { evaluable } \\
\text { subjects) }\end{array}$ & [22] \\
\hline (I) Cordyceps sinensis & $\begin{array}{l}\text { Cordyceps sinensis with low } \\
\text { dose of cyclosporin A }\end{array}$ & & $\begin{array}{l}\text { A. Cytokine } \\
\text { No significant difference in } \\
\text { IL-2 in the two groups. } \\
\text { IL-10 in the treatment group } \\
\text { was significantly }(p<0.05) \\
\text { higher than that in control } \\
\text { group. } \\
\text { B. Cell subset - NA }\end{array}$ & $\begin{array}{l}\text { Renal transplant } \\
\text { patients }\end{array}$ & [23] \\
\hline $\begin{array}{l}\text { (I) Astragalus } \\
\text { membranaceus } \\
\text { polysaccharide }\end{array}$ & $\begin{array}{l}\text { Injection of astragalus extract } \\
\text { (AI) }\end{array}$ & $\begin{array}{l}\text { Al } 20 \mathrm{ml} \text { was added } \\
\text { into } 250 \mathrm{ml} \text { of } 5 \% \\
\text { glucose solution } \\
\text { given through } \\
\text { intravenous dripping. } \\
\text { Randomly assigned } \\
\text { into conventional } \\
\text { group and the } \\
\text { treated group. } \\
\text { Patients in the } \\
\text { conventional } \\
\text { group were given } \\
\text { conventional } \\
\text { treatment, while } \\
\text { patients in the } \\
\text { treated group were } \\
\text { given conventional } \\
\text { treatment and Al. } \\
\text { Measurement on the } \\
1 \text { st and 14th day }\end{array}$ & $\begin{array}{l}\text { A. Cytokine - NA } \\
\text { B. Cell subset } \\
\mathrm{CD}^{+}, \mathrm{CD} 4^{+}, \mathrm{CD} 4^{+} / \mathrm{CD} 8^{+} \text {, } \\
\mathrm{CD} 16^{+}, \mathrm{CD} 69^{+} \text {of the treated } \\
\text { group, higher than those } \\
\text { of conventional group } \\
(P<0.05) ; \mathrm{CD} 8^{+} \text {lower than } \\
\text { that of conventional group } \\
(P<0.05) \text {. }\end{array}$ & $\begin{array}{l}36 \text { Abdominal } \\
\text { trauma patients }\end{array}$ & [24] \\
\hline
\end{tabular}


(I) 1.

Eleutherococcus senticosus
Treatment group received 10 $\mathrm{ml}$ of ethanolic (vincamine free)

\section{Eleutherococcus} senticosus preparation, 3 times daily for 4 weeks, in comparison with placebo ethanolic group
A. Cytokine - NA

B. Cell subset

Significant increase in absolute number of total lymphocyte $(p<0.0001)$ Pronounced effect on T-helper $(p<0.00001)$ and T-suppressor cells $(p<0,0001)$, NK cells $(p<0.01)$ and B-lymphocyte $(p<0.05)$
Placebocontrolled, doubleblinded study
$33 \%$ ethanolic extract $(8 \mathrm{~mL}$ ) day) containing either ES, $\mathrm{PG}$ (equivalent to $4 \mathrm{~g} /$ day and $2 \mathrm{~g} /$ day of dried root

\section{A. Cytokine - NA}

B. Cell subset

No significant change for total T cells, T helper cells (CD4), T suppressor cells (CD8), CD4 to CD8 ratio, NK cells, and B lymphocytes

CD: Cluster of differentiation; ES: Eleutherococcus senticosus; IFN: Interferon; IL: Interleukin; NA: Not applicable; NK: Natural killer; PBL: Peripheral blood lymphocytes; PG: Panax ginseng; TNF: Tumor necrosis factor.

strains. There are two well-known commercial preparations of polysaccharide of Coriolus versicolor -- polysaccharide peptide (PSP, produced in China) and polysaccharide Krestin (PSK, produced in Japan).

Coriolus versicolor has been extensively investigated in phase I, II and III randomized clinical trials in esophageal, breast, colorectal and stomach cancer patients in Asia [27]. Since 1970, many large scale clinical research studies have been conducted mainly in Japan. Among the 35 randomized controlled trials on Coriolus versicolor conducted in Asia, more than half of these were of gastric cancer $(n=19)$ and with 13,498 patients participated [28$45]$. A quarter of the studies were of colorectal cancer $(n=9)$ and with 2,194 patients involved [29,46-54]. Only a few clinical trials on esophageal $(n=3)$ [55-57] and breast cancer $(n=4)$ [58-61] with 532 patients and 2,217 patients respectively.

Most of the above-mentioned clinical research studies focus on the adjuvant therapy of Coriolus versicolor in combination with conventional drug on disease-free survival and overall survival rates. The adjuvant chemotherapy improved the 15year survival rate for patients following curative resection. The overall survival durations for cancer patients have been shown to be significantly longer with Coriolus versicolor as the supplement for chemotherapy. These reviews concluded that PSK exert definite beneficial effects on esophageal, breast, colorectal and stomach cancer patients $[32,46,59,62]$. However, these reviews did not describe the effects on immunological markers profiles. A review of the original clinical trial research papers mentioned in the above-mentioned meta-analysis articles revealed some useful papers that have documented the patients' immunological changes accompanying the improvement of the tumor responses and overall patients' survival.

One of the key immunological effects of Coriolus versicolor is activation of blood NK cells. For instance, the group of Sadahiro et al. conducted a randomized trial of 30 cancer patients with adenocarcinoma of middle or lower rectum (CT3/CT4). Patients were randomized into the control group $(n=15)$ and the PSK (Polysaccharide-Krestin, protein-bound polysaccharide) group $(n=15)$. Both groups received two weeks' chemoradiotherapy and four weeks' S-1 administration (Taiho Pharmaceutical Co., Japan) $80 \mathrm{mg} / \mathrm{m}^{2} /$ day divided into two daily doses before surgery (control group). The PSK group was treated the same chemo radiotherapy with simultaneous four weeks' PSK administration PSK (Kureha Corporation, Japan) $3 \mathrm{~g} /$ day divided into three daily doses, for four weeks. It was found that PSK group has a significant increase of NK cells by $5 \%$ in the peripheral blood $(P=0.003)$ [13]. Furthermore, CD8 cytotoxic T cell counts increased by $153 \%$ $(P=0.005)$ and $151 \%$ in the peri-tumoral and normal mucosa $(p=0.003)$ respectively. The researchers therefore concluded that PSK may upregulate both the innate and humoral responses.

Another immune cell type that PSK has shown to have regulatory effect is a T cell subset of that expresses the NK marker CD57. The significance of these $C D 57^{+}$T cells has been shown in an initial study of 48 patients with advanced-stage gastric carcinoma (stage III-IV, n2, and T3-4) such that patients with a higher proportion of $\mathrm{CD} 57^{+} \mathrm{T}$ cells $(\geq 18 \%$ ) was associated with poorer survival compared with the group of lower $C D 57^{+}$T cells $(<18 \%)(p=0.046)$ [63]. The researchers proposed that in patients with advanced carcinomas (stage III-IV), but not the early cancer stages (stage $\mathrm{I}-\mathrm{II}$ ), the proportion of $\mathrm{CD} 57^{+} \mathrm{T}$ cells was able to predict patients with a poorer prognosis. Akagi and Baba [14] then reported a clinical trial with 21 patients randomly assigned to receive either $3 \mathrm{~g}$ PSK plus $300 \mathrm{mg}$ tegafur/uracil (PSK group) or $300 \mathrm{mg}$ tegafur/ uracil alone (control) orally each day for at least 1 year after operation. The 3 -year overall survival was $62.2 \%$ in the PSK group and $12.5 \%$ in the control group. This survival advantage in the PSK group was correlated with decreased $\mathrm{CD} 57^{+} \mathrm{T}$ cells decreased compared to the control $(\boldsymbol{p}<0.0486)$.

Not all reported studies in Coriolus versicolor used the processed PSK products. Torkelson et al. [15] launched a phase 1 clinical trial of Coriolus versicolor in 11 women with breast cancer by oral treatment of Coriolus versicolor freeze-dried mycelial powder. Each capsule contained $500 \mathrm{mg}$ of product with each cohort comprised of three participants given one of three doses of Coriolus vesicolor (3, 6 or $9 \mathrm{~g}$ ). For the 9 women completed 
study, lymphocyte counts were observed to increase at $6 \mathrm{~g} /$ day and $9 \mathrm{~g} /$ day. NK cell functional activity measured by the number of effector cells (NK) required to achieve $20 \%$ specific lyses on the target cells (K562) was found to increase at $6 \mathrm{~g} /$ day. Dose-related increases in $\mathrm{CD}^{+} \mathrm{T}$ cells and $\mathrm{CD} 19^{+} \mathrm{B}$ cells but not $\mathrm{CD} 4^{+} \mathrm{T}$ cells or $\mathrm{CD} 16^{+} 56^{+} \mathrm{NK}$ cells were also reported. It is to be noted that with such small number of patients participated in the study, the results were not statistically significant.

In summary, the use of Coriolus versicolor, in either the processed form of PSK or the freeze dried mycelial powder of the medicinal mushroom has shown to be related to increase of both the numbers and functional activities of the blood NK cells.

\section{Ganoderma lucidum}

Clinical trials on the medicinal mushroom Ganoderma lucidum have been conducted on healthy subjects and cancer patients using extracts from the spores or fruiting bodies or a combination of these. A few reports have used Ganopoly which is the aqueous polysaccharides fraction extracted from Ganoderma lucidum. It was prepared from the fruiting bodies of wood-cultured Ganoderma lucidum which were collected from southern China. The polysaccharides were consisted of $61.2 \%$ glucose, $15.5 \%$ xylose, $14.4 \%$ fructose, $4.8 \%$ galactose and $4.1 \%$ rhamnose and were linked together by $\beta$-glycosidic linkages. The concentration of proteins was $0.35 \%$ [64]. The polysaccharide extracts were dark red powder packed as capsules by Alpha Pharmaceuticals of New Zealand according to GMP standard. The total dose is equivalent to $270 \mathrm{~g}$ fruiting body of Ganoderma lucidum.

Two clinical trials have been reported using this Ganopoly extract. The first clinical trial. was a non-randomized, non-placebo trial comparing with baseline treatment of $1,800 \mathrm{mg}$ Ganopoly, three times daily orally before meals for 12 weeks on 34 advanced-stage cancer patients with diverse cancer origins including lung, colon, breast, liver, prostate, bladder, and brain [16]. Examination of the serum cytokines of 30 patients assessed for immune function after 12 weeks revealed significant increased IL-2, IL- 6 and IFN- $\gamma$ and also significant decreased IL-1 and TNF- $\alpha$ levels. The mean absolute number of $\mathrm{CD}^{2} 6^{+}$cells and NK cell activity were also significantly increased.

Another follow-up randomized, double-blind, placebo-controlled, multi-centre clinical trial from the same research group focusing on advanced-stage III to IV lung cancer patients applied the same protocol of 12 weeks of treatment with the same oral Ganopoly or placebo at a dose of three capsules $(600 \mathrm{mg} \times 3=1800 \mathrm{mg}) 3$ times daily before meal [17]. Total dose of $5,400 \mathrm{mg}$ of Ganopoly per day was equivalent to $270 \mathrm{~g}$ fruiting body of Ganoderma lucidum. In this study, 68 lung cancer patients of were recruited and randomized into Ganopoly group of 37 patients and placebo group of 31 patients. For the Ganopoly treatment group of 32 patients assessable at the end of 12 weeks treatment, CD3 percentage and NK cell activity were significantly increased whereas the other parameters were no significant changes [17]. Chen et al. [18] initiated a non-randomized open-labeled study on oral treatment of water-soluble Ganoderma lucidum polysaccharides with $1,800 \mathrm{mg}$ three times daily of Ganoderma lucidum $5,400 \mathrm{mg} /$ day was equivalent to $81 \mathrm{~g}$ fruiting body before meals for 12 weeks. In this study, 47 patients of advanced-stage III to IV colorectal cancer were recruited but only 41 patients assessable in the final measurement. For serum cytokine study, there was a trend of increase of cytokines of IL-2, IL-6 and IFN- $\gamma$ by $0.2 \%, 6.3 \%$ and $8.8 \%$ but did not reach statistical significance. There was also a trend of IL- 1 and TNF- $\alpha$ decrease by $9.6 \%$ and $8.7 \%$ but again with no statistical significance. In the same study, the number of CD3, CD4, CD8 and CD56 lymphocytes also showed a trend of increase. Similarly the NK cells activity was found to be increased but did not achieve statistical significance. This reflects the requirement of bigger numbers of the patient pool in the immunological studies to overcome the diverse difference in the baseline values of various immunological parameters and diverse responses to the specific herbal medicines.

Zhang et al. [20] conducted a study on 40 male football players. Three groups labeled as LHTL1, LHTL2 and LHTL3 groups were provided with placebo, Ganoderma lucidum ten capsules (2.5 g/day) and Ganoderma lucidum 20 capsules ( $5 \mathrm{~g} /$ day) for six weeks (two weeks baseline supplementation followed by 28 days of the treatment protocol). These Ganoderma lucidum capsules contained total extract isolated from the fruiting body of Ganoderma lucidum by boiling water and mixed with pure pores at a ratio of 7:2. LHTL3 group ( $5 \mathrm{~g} /$ day) was found increased significantly the percentage of $\mathrm{CD}^{+}, \mathrm{CD}^{+}$cells compared with the LHTL1 placebo group.

Zhao et al. [21] investigated the effects of spore powder of Ganoderma lucidum containing polysaccharides, triterpenoids, alkaloids, enzymes and proteins at 1,000 $\mathrm{mg}$ three times a day for four weeks on breast cancer patients by a randomized, placebo controlled trial. 48 breast cancer patients of stage I to IIIA were selected for the study. Cytokine levels of TNF- $\alpha$ and IL- 6 were found to be significantly lowered. The mean serum TNF- $\alpha$ levels at pre- and post-treatment in the Ganoderma group were detected as $128.7 \mathrm{pg} / \mathrm{mL}$ and $71.9 \mathrm{pg} / \mathrm{mL}$ respectively. Similarly, the mean serum levels of IL-6 pre- and post-treatment in the Ganoderma group were found to be $62.4 \mathrm{pg} / \mathrm{mL}$ and $37.6 \mathrm{pg} / \mathrm{mL}$ respectively.

A randomized, double-blind, cross-over trial with placebocontrolled run-in and cross-over periods on 26 patients with hypertension and or dyslipidemia was conducted by Chu et al. [22]. Treatment of 12 weeks was each on Ganoderma lucidum treatment or on matching placebo. The dosage was $1.44 \mathrm{~g}$ Ganoderma lucidum extract taken with two capsules (each capsule contains $360 \mathrm{mg}$ extract) twice daily, which was equivalent to 13.2 $\mathrm{g}$ of the fresh mushroom (recommended dose of Ganoderma lucidum in the Chinese Materia Medica of 11.25-18.75 g of fresh material). In this study, 26 patients with hypertension and or dyslipidemia were recruited with final 23 evaluable subjects. Both the cell counts and percentages of the B lymphocytes and $T$ helper cell were found decreased during the Ganoderma lucidum treatment but the changes were not significantly different from those of the placebo treatment.

Wachtel-Galor et al. conducted a double-blinded, placebocontrolled and cross-over intervention study on 18 healthy subjects of aged 22-52 years were enrolled for four weeks supplementation with a commercially available encapsulated Ganoderma lucidum preparation (1.44 g Ganoderma lucidum per 
day equivalent to $13.2 \mathrm{~g}$ fresh mushroom per day) [12]. The mean CD4:CD8 ratio for the placebo group was 1.6 on Day 1 and 1.5 on Day 29 whereas that for the Ganoderma lucidum group was 1.5 on Day 1 and 1.6 on Day 29. As the mean CD4:CD8 ratio was more or less the same between the Ganoderma lucidum treatment group and placebo group, it led to achieving no statistical significance. Both the innate and humoral responses were not enhanced in these healthy subjects.

A double-blind randomized placebo-controlled trial on 16 cancer patients was led by Wicks et al. [19] in 2007. In this study, $2 \mathrm{~g}$ of the Ganoderma lucidum extract contained $1.89 \%$ of terpenoids and $15.8 \%$ of polysaccharides or placebo treatment twice daily for ten consecutive days. Oral doses of Ganoderma lucidum extract or placebo were four capsules each time. 16 normal subjects with eight male and eight non-pregnant female were also included in the study. A short-term increase of CD56 NK cells that sustained for only ten days after intake of Ganoderma lucidum extract was found. The CD4, CD8, CD19 cell counts were demonstrated with no obvious change. All these results were not statistically significant.

In summary for Ganoderma lucidum immunological effect, both the NK cell number and activity were significantly increased. The levels of serum cytokines of IL-2, IL- 6 and IFN- $\gamma$ were found to be significantly increased. It is to be noted that these cytokines can stimulate in turn an array of immunological important cell types of T cells, B cells and dendritic cells. On the other hand, the inflammatory cytokines of IL-1 and TNF- $\alpha$ were found to be significantly decreased with the use of Ganoderma lucidum.

\section{Cordyceps sinensis}

Ding et al. [23] investigated the efficacy of Cordyceps sinensis (CS) in long term treatment of renal transplant patients. The renal function and survival rates of grafts and patients did not show significantly difference between the control group and the treatment group. However, the incidences of complications were significantly lower in the treatment group compared with that in control group with the exception of those showing acute rejection. It was reported that the serum level of IL-10 in the treatment group was significantly higher than that in control group. However, there was no significant difference in the serum level of IL-2 in these two groups. These data demonstrated that CS might be used in combination with a low dose of CsA in the long term treatment of kidney transplant patients. This result was agreed by another evidence-based systematic review stating that Ding's group finding of Cordyceps in combination with low dose of cyclosporin $A$ is effective as an immunosuppressant agent in the treatment of renal transplant patients [65].

\section{Astragalus membranaceus}

An injection of astragalus extract called Milkvetch Injection (MI) was found to be useful at significantly improving immune function in children after major surgery to correct tetralogy of Fallot compared to standard treatment [66]. This study was to evaluate the effect of $\mathrm{MI}$ on immune function of children with tetralogy of Fallot after radical operation. In this study, 40 young patients were equally divided into two groups of 20 . The control group was treated with conventional treatment alone and the other group received both conventional treatment and $15 \mathrm{ml}$ of MI every 12 hours for 14 days.

In the MI-treated group, the abnormally increased levels of IgG, IgM, C3, C4, CD8 ${ }^{+}$cells and $\mathrm{CD} 19^{+}$cells began to lower at Ist- $2^{\text {nd }}$ week after treatment, and basically restored to the levels of normal at the $3^{\text {rd }}-4^{\text {th }}$ week. In the same patient group, the original decreased levels of $\operatorname{IgA}, \mathrm{CD}^{+}$cells, $\mathrm{CD}^{+}$cells, $\mathrm{CD}^{+}$/ $\mathrm{CD}^{+}$ratio, $\mathrm{CD}^{+} / \mathrm{HLA}-\mathrm{DR}^{+}$cells and $\mathrm{CD} 16^{+} \mathrm{CD} 56^{+}$cells at base line raised gradually from the $1^{\text {st }}$ week and restored to normal range at $2^{\text {nd }}-3^{\text {rd }}$ week. The plasma IL- 6 and tumor necrosis factoralpha (TNF- $\alpha$ ) levels in the same MI-treated group were found to decrease gradually at the 1st week and restored to the normal level at the $3^{\text {rd }}-4^{\text {th }}$ weeks $(p<0.05)$.

This same injection of Astragalus extract was reported to help restoring normal cellular immunity in patients who had suffered major abdominal trauma according to a clinical trial lead by $\mathrm{Wu}$ et al. in China [24]. A total of 36 serious abdominal traumatic patients were randomly assigned into two groups, the control group and the Ml-treated group, patients in the control group were given conventional treatment, while others in the treated group were given conventional treatment plus $\mathrm{MI} 20 \mathrm{~mL}$ injection mixed in $250 \mathrm{~mL}$ of $5 \%$ glucose solution given through intravenous dripping. T cell activated antigens of these two groups together with 10 healthy subjects were simultaneously monitored on the first day and the $14^{\text {th }}$ day. On the first day, in the control group and MI-treated group, the cell counts of cells expressing the surface markers of $\mathrm{CD}^{+}, \mathrm{CD}^{+}, \mathrm{CD}^{+} / \mathrm{CD}^{+}, \mathrm{CD} 16^{+}, \mathrm{CD} 9^{+}$and $\mathrm{CD}^{+} /$ human $\mathrm{HLA}-\mathrm{DR}^{+}$were apparently lower than the healthy subjects $(p<0.05)$, and there was no significant difference between the conventional group and the treated group $(P>0.05)$. Then on the $14^{\text {th }}$ days, the cell numbers of $\mathrm{CD}^{+}, \mathrm{CD}^{+}, \mathrm{CD} 4^{+} / \mathrm{CD} 8^{+}, \mathrm{CD} 16^{+}$, $\mathrm{CD} 9^{+}$and $\mathrm{CD}^{+} / \mathrm{HLA}^{-\mathrm{DR}^{+}}$of the $\mathrm{Ml}$-treated group got closed to healthy subject value, and higher than those of conventional group $(P<0.05)$. The researchers concluded that $\mathrm{MI}$ can enhance the cellular immunity aspect and confirmed the findings with further immunological and anti-tumor studies in vitro and in vivo $[67,68]$.

\section{Eleutherococcus senticosus}

A placebo-controlled, double-blinded study was conducted by Bohn et al. [25] to investigate the immunological effects of an Eleutherococcus senticosus ethanolic extract (Eleukokk) in 36 healthy volunteers. The treatment group received $10 \mathrm{~mL}$ of Eleukokk, three times daily for four weeks, whereas for the placebo, the Eleutherococcus senticosus extract was substituted by additional wine, resulting in identical final concentrations of ethanol in both preparations. There was an increase of total lymphocyte $(p<0.0001)$, in particularly the $C D 4^{+} \mathrm{T}$ helper cells $(p<0.00001)$, but also on CD8 ${ }^{+} T$ suppressor cells $(P<0.0001)$, and $\mathrm{CD} 19^{+} \mathrm{B}$ cells $(p<0.05)$ compared with placebo. However, there was no significant difference in the change of NK cells.

Gaffney et al. [26] initiated a clinical trial was undertaken to investigate the effects of Eleutherococcus senticosus and Panax ginseng on competitive club-level endurance athletes engaged in their normal in-season training. Participants were matched for training stress and received a $33 \%$ ethanolic extract $(8 \mathrm{~mL} /$ 
day) containing either Eleutherococcus senticosus, Panax ginseng (equivalent to $4 \mathrm{~g}$ and $2 \mathrm{~g}$ /day of dried root, respectively), or a placebo. A pre-test and post-test were used to evaluate the effects of six weeks of supplementation on cortisol, testosterone, and testosterone to cortisol ratio well as circulating numbers of total $\mathrm{T}$ cells, $\mathrm{CD} 4^{+} \mathrm{T}$ helper cells, $\mathrm{CD} 8^{+} \mathrm{T}$ suppressor cells, CD4/ $\mathrm{CD} 8$ ratio, $\mathrm{CD} 16^{+} \mathrm{CD} 56^{+} \mathrm{NK}$ cells, and $\mathrm{CD} 19^{+} \mathrm{B}$ cells. None of the immune system variables changed significantly nor showed any clear trend from pre- to post-test in any of the treatment groups. The only significant result was that for the Eleutherococcus group there was a decrease of the testosterone to cortisol ratio by $29 \%$ from 0.047 to 0.033 . However, this study suffered from the drawback of incapable to distinguish the individual effect of Eleutherococcus senticosus and Panax ginseng.

\section{Conclusions}

In this review of the two mushrooms Coriolus versicolor and Ganoderma lucidum, the promising clinical effects are found to be related to a concurrent activation of some immune cell populations in particularly the NK cells. NK cell population can be regarded as the most important cell type for our innate immunity for the first line of defense against disease $[69,70]$. The major subset of (90\%) the NK cells are equipped with strong cytolytic activities against target cells [71]. However before these medicinal mushrooms can be considered as suitable future target therapeutic agents, more high-quality, long-term doubleblinded, placebo-controlled studies with large trial populations are definitely required.

This review also identified a clear research gap of the lack of laboratory investigation of the major immune cell population of Dendritic Cell (DC). DCs are competent professional antigen presenting cell to present the target antigens by first priming the naïve $T$ cells $[72,73]$ to initiate both the antigen-specific $B$ and $T$ cell responses. Essentially the DC, B cells and T cells as a triad constitutes the adaptive immunity. Furthermore, there are at least 5 different DC subsets in human blood [73]. Therefore future clinical trials of these potentially clinical useful medicinal mushrooms and herbs should also focus at the blood DC and its various subsets in blood to provide a more comprehensive multidirectional network of mechanisms of action. 


\section{References}

1 Qi F, Li A, Inagaki Y, Gao J, Li J, et al. (2010) Chinese herbal medicines as adjuvant treatment during chemo-or radio-therapy for cancer. Biosci Trends 4: 297-307.

2 Sze DMY, Brown R, Yang S, Ho PJ, Gibson J, et al. (2006) The use of thalidomide in myeloma therapy as an effective anticancer drug. Current cancer drug targets 6: 325-331.

3 Sze DMY, Chan GCF (2009) Supplements for immune enhancement in hematologic malignancies. ASH Education Program Book 2009: 313-319.

4 Li S, Zhang B (2013) Traditional Chinese medicine network pharmacology: theory, methodology and application. Chinese Journal of Natural Medicines 11: 110-120.

5 Ooi VEC, Liu F (2000) Immunomodulation and anti-cancer activity of polysaccharide-protein complexes. Current Medicinal Chemistry 7: 715-729.

6 Kidd PM (2000) The use of mushroom glucans and proteoglycans in cancer treatment. Alternative Medicine Review 5: 4-27.

7 Ma HT, Hsieh JF, Chen ST (2014) Anti-diabetic effects of Ganoderma lucidum. Phytochemistry 114: 109-113.

8 Wasser SP (1998) Medicinal mushroom science: Current perspectives, advances, evidences, and challenges. Biomedical journal 37: 345

9 Chan GC, Chan WK, Sze DM (2009) The effects of beta-glucan on human immune and cancer cells. J Hematol Oncol 2: 1-11.

10 Sze DM, Liu H, Boost MV, Wong R, Sagar S (2015) Phytotherapeutics for cancer therapy. Phytotherapies: Efficacy, Safety and Regulation. p: 394.

11 Wasser SP (2011) Current findings, future trends, and unsolved problems in studies of medicinal mushrooms. Applied microbiology and biotechnology 89: 1323-1332.

12 Wachtel-Galor S, Tomlinson B, Benzie IFF (2004) Ganoderma lucidum ('Lingzhi'), a Chinese medicinal mushroom: biomarker responses in a controlled human supplementation study. British Journal of Nutrition 91: 263-269.

13 Sadahiro S, Suzuki T, Maeda Y, Tanaka A, Kamijo A, et al. (2010) Effects of preoperative immunochemoradiotherapy and chemoradiotherapy on immune responses in patients with rectal adenocarcinoma. Anticancer research 30: 993-999.

14 Akagi J, Baba H (2010) PSK may suppress CD57+ T cells to improve survival of advanced gastric cancer patients. International journal of clinical oncology 15: 145-152.

15 Torkelson CJ, Sweet E, Martzen MR, Sasagawa M, Wenner CA, et al. (2012) Phase 1 clinical trial of Trametes versicolor in women with breast cancer. ISRN oncology.

16 Gao Y, Zhou S, Jiang W, Huang M, Dai X (2003) Effects of Ganopoly A Ganoderma lucidum Polysaccharide Extract) on the Immune Functions in Advanced-stage Cancer Patients. Immunological investigations 32: 201-215.

17 Gao Y, Dai X, Chen G, Ye J, Zhou S (2003) A randomized, placebocontrolled, multicenter study of Ganoderma lucidum (W. Curt.: Fr.) LLoyd (Aphyllophoromycetideae) polysaccharides (Ganopoly(R)) in patients with advanced lung cancer. International Journal of Medicinal Mushrooms 5: 369-381.

18 Chen X, Hu ZP, Yang XX, Huang M, Gao Y, et al. (2006) Monitoring of immune responses to a herbal immuno-modulator in patients with advanced colorectal cancer. International immunopharmacology 6 : 499-508.

19 Wicks SM, Tong R, Wang CZ, O'Connor M, Karrison T, et al. (2007) Safety and tolerability of Ganoderma lucidum in healthy subjects: a double-blind randomized placebo-controlled trial. The American journal of Chinese medicine 35: 407-414.

20 Zhang Y, Lin Z, Hu Y, Wang F (2008) Effect of Ganoderma lucidum capsules on T lymphocyte subsets in football players on "living hightraining low". British journal of sports medicine 42: 819-822.

21 Zhao H, Zhang Q, Zhao L, Huang X, Wang J, et al. (2011) Spore powder of Ganoderma lucidum improves cancer-related fatigue in breast cancer patients undergoing endocrine therapy: a pilot clinical trial. Evidence-Based Complementary and Alternative Medicine.

22 Chu TTW, Benzie IFF, Lam CWK, Fok BSP, Lee KKC, et al. (2012) Study of potential cardioprotective effects of Ganoderma lucidum (Lingzhi): results of a controlled human intervention trial. British Journal of Nutrition 107: 1017-1027.

23 Ding C, Tian PX, Xue W, Ding X, Yan H, et al. (2010) Efficacy of Cordyceps sinensis in long term treatment of renal transplant patients. Frontiers in bioscience (Elite edition 3: 301-307.

24 Wu J, Wang YX, Su WL, Zhu WX, Lu JW, et al. (2006) Effect of astragalus injection on serious abdominal traumatic patients' cellular immunity. Chinese Journal of Integrative Medicine 12: 29-31.

25 Bohn B, Nebe CT, Birr C (1987) Flow-cytometric studies with eleutherococcus senticosus extract as an immunomodulatory agent. Arzneimittel-Forschung 37: 1193-1196.

26 Gaffney BT, Hugel HM, Rich PA (2001) The effects of Eleutherococcus senticosus and Panax ginseng on steroidal hormone indices of stress and lymphocyte subset numbers in endurance athletes. Life Sciences 70: $431-442$

27 Standish LJ, Wenner CA, Sweet ES, Bridge C, Nelson A, et al. (2008) Trametes versicolor mushroom immune therapy in breast cancer Journal of the Society for Integrative Oncology 6: 122-128.

28 Maehara $\mathrm{Y}$, Sugimachi K, Akagi M, Kakegawa T, Shimazu H, et al. (1992) Early postoperative chemotherapy following noncurative resection for patients with advanced gastric cancer. British journal of cancer 65: 413-416.

29 Nio Y, Tsubono M, Tseng CC, Morimoto H, Kawabata K, et al. (1992) Immunomodulation by orally administered protein-bound polysaccharide PSK in patients with gastrointestinal cancer. Biotherapy 4: 117-128.

30 Sakamoto J, Koike A, Saji S, Teramukai S, Ohashi Y, et al. (1992) Preoperative serum immunosuppressive acidic protein (IAP) test for the prognosis of gastric cancer: a statistical study of the threshold level and evaluation of the effect of the biological response modifier PSK. Surgery today 22: 530-536.

31 Kondo T, Sakamoto J, Nakazato H (1991) Alternating immunochemotherapy of advanced gastric carcinoma: a randomized comparison of carbazilquinone and PSK to carbazilquinone in patients with curative gastric resection. Biotherapy 3: 287-295.

32 Maehara Y, Moriguchi S, Sakaguchi Y, Emi Y, Kohnoe S, et al. (1990) Adjuvant chemotherapy enhances long-term survival of patients with advanced gastric cancer following curative resection. Journal of Surgical Oncology 45: 169-172.

33 Imaizumi M, Kondo T, Kamei H, Ichihashi H (1990) Cooperative 
study on surgical adjuvant immunochemotherapy for prevention of postoperative recurrence of gastric cancer (II). Cooperative study group on surgical adjuvant immunochemotherapy for prevention of postoperative recurrence of gastric cancer supported by the Ministry of Health and Welfare. Cancer \& chemotherapy 17: 2397-2403.

34 Nakajima T, Inokuchi K, Hattori T, Inoue K, Taguchi T, et al. (1989) Multiinstitutional cooperative study of adjuvant immunochemotherapy in gastric cancer--five-year survival rate. Cancer \& chemotherapy 16 : 799-806

35 Nakazato H, Koike A, Ichihashi H, Saji S, Danno M, et al. (1989) An effect of adjuvant immunochemotherapy using krestin and 5-FU on gastric cancer patients with radical surgery (first report)--a randomized controlled trial by the cooperative study group. Study Group of Immuno-chemotherapy with PSK for Gastric Cancer. Cancer \& chemotherapy 8: 2563-2576.

36 Tamada R, Inokuchi K, Hattori T, Inoue K, Taguchi T, et al. (1987) A multiinstitutional study on postoperative adjuvant immunochemotherapy of gastric cancer (II). Cancer \& chemotherapy 3: 716-722.

37 Niimoto M, Hattori T, Tamada R, Sugimachi K, Inokuchi K, et al. (1998) Postoperative adjuvant immunochemotherapy with mitomycin $\mathrm{C}$, futraful and PSK for gastric cancer. An analysis of data on 579 patients followed for five years. The Japanese journal of surgery 18: 681-686.

38 Kanabe S, Tamakuma S, Mimura K, Hiraide H, Mochizuki H, et al. (1985) Comparison of immunochemotherapy and chemotherapy of stage IV gastric carcinoma. Gan no rinsho Japan journal of cancer clinics 31: 1805-1809.

39 Nakazato H, Ichihashi H, Kondo T (1986) Clinical results of a randomized controlled trial on the effect of adjuvant immunochemotherapy using Esquinon and Krestin in patients with curatively resected gastric cancer. Cooperative Study Group of Cancer Immunochemotherapy, Tokai Gastrointestinal Oncology Group. Gan to kagaku ryoho Cancer \& chemotherapy 13: 308-318.

40 Nakazato H, Koike A, Saji S, Ogawa N, Sakamoto J, et al. (1994) Efficacy of immunochemotherapy as adjuvant treatment after curative resection of gastric cancer. The Lancet 343: 1122-1126.

41 Osawa S, Shiroto H, Kondo Y, Nakanishi Y, Fujisawa J, et al. (1996) Randomized controlled study on adjuvant immunochemotherapy with carmofur (HCFU) for noncuratively resected and unresected gastric cancer. Cancer \& chemotherapy 23: 327-331.

42 Sugimachi K, Maehara Y, Ogawa M, Kakegawa T, Tomita M (1997) Dose intensity of uracil and tegafur in postoperative chemotherapy for patients with poorly differentiated gastric cancer. Cancer chemotherapy and pharmacology 40: 233-238.

43 Ogoshi K, Tajima T, Mitomi T, Makuuchi H, Tsuji K (1997) HLA-A2 antigen status predicts metastasis and response to immunotherapy in gastric cancer. Cancer Immunology, Immunotherapy 45: 53-59.

44 Toge T, Yamaguchi Y (2000) Protein-bound polysaccharide increases survival in resected gastric cancer cases stratified with a preoperative granulocyte and lymphocyte count. Oncology reports 7: 1157-1218.

45 Ueda Y, Fujimura T, Kinami S, Hirono Y, Yamaguchi A, et al. (2006) A randomized phase III trial of postoperative adjuvant therapy with S-1 alone versus S-1 plus PSK for stage II/IIIA gastric cancer: HokurikuKinki Immunochemo-Therapy Study Group-Gastric Cancer (HKITGC). Japanese journal of clinical oncology 36: 519-522.

46 Ito K, Nakazato H, Koike A, Takagi H, Saji S, et al. (2004) Long-term effect of 5-fluorouracil enhanced by intermittent administration of polysaccharide $\mathrm{K}$ after curative resection of colon cancer. International journal of colorectal disease 19: 157-164.
47 Mitomi T, Tsuchiya S, lijima N, Aso K, Suzuki K, et al. (1992) Randomized, controlled study on adjuvant immunochemotherapy with PSK $(R)$ in curatively resected colorectal cancer. Diseases of the Colon \& Rectum 35: 123-130.

48 Torisu $\mathrm{M}$, Hayashi $\mathrm{Y}$, Ishimitsu T, Fujimura T, Iwasaki $\mathrm{K}$, et al. (1990) Significant prolongation of disease-free period gained by oral polysaccharide K (PSK) administration after curative surgical operation of colorectal cancer. Cancer Immunology, Immunotherapy 31: 261-268.

49 Takashima S, Kinami Y, Miyazaki I (1988) Clinical effect of postoperative adjuvant immunochemotherapy with the FT-207 suppository and PSK in colorectal cancer patients. Colorectal Cancer Chemotherapy Group in Hokuriku. Cancer \& chemotherapy 15: 2229-2236.

50 Munemoto Y, lida Y, Abe J, Saito H, Fujisawa K, et al. (2002) Significance of postoperative adjuvant immunochemotherapy after curative resection of colorectal cancers: association between host or tumor factors and survival. International journal of oncology 20: 403-411.

51 Shibata M, Nezu T, Kanou H, Nagata Y, Kimura T, et al. (2002) Immunomodulatory effects of low dose cis-Diaminedichloroplatinum (cisplatin) combined with UFT and PSK in patients with advanced colorectal cancer. Cancer investigation 20: 166-173.

52 Koda K, Miyazaki M, Sarashina H, Suwa T, Saito N, et al. (2003) A randomized controlled trial of postoperative adjuvant immunochemotherapy for colorectal cancer with oral medicines. International journal of oncology 23: 165-172.

53 Ohwada S, Kawate S, Ikeya T, Yokomori T, Kusaba T, et al. (2003) Adjuvant therapy with protein-bound polysaccharide $\mathrm{K}$ and tegafur uracil in patients with stage II or III colorectal cancer: randomized, controlled trial. Diseases of the Colon \& Rectum 46: 1060-1068.

54 Yamashita K, Ougolkov AV, Nakazato H, Ito K, Ohashi Y, et al. (2007) Adjuvant immunochemotherapy with protein-bound polysaccharide $\mathrm{K}$ for colon cancer in relation to oncogenic B-catenin activation. Diseases of the Colon \& Rectum 50: 1169-1181.

55 Ogoshi K, Satou H, Isono K, Mitomi T, Endoh M, et al. (1995) Possible predictive markers of immunotherapy in esophageal cancer: retrospective analysis of a randomized study. Cancer investigation 13: 363-369.

56 Ogoshi K, Satou H, Isono K, Mitomi T, Endoh M (1995) Immunotherapy for Esophageal Cancer: A Randomized Trial in Combination with Radiotherapy and Radiochemotherapy. American journal of clinical oncology 18: 216-222.

57 Ogoshi K (1988) Evaluation of immunotherapy with PSK in esophageal cancer. Cancer \& chemotherapy 15: 3143-3151.

58 Toil M, Hattori T, Akagi M, Lnokuchi K, Orita K, et al. (1992) Randomized adjuvant trial to evaluate the addition of tamoxifen and PSK to chemotherapy in patients with primary breast cancer: 5-year results from the nishi-nippon group of the adjuvant chemoendocrine therapy for breast cancer organization. Cancer 70: 2475-2483.

59 Morimoto T, Ogawa M, Orita K, Sugimachi K, Toge T, et al. (1996) Postoperative adjuvant randomised trial comparing chemoendocrine therapy, chemotherapy and immunotherapy for patients with stage II breast cancer: 5-year results from the Nishinihon Cooperative Study Group of Adjuvant Chemoendocrine Therapy for Breast Cancer (ACETBC) of Japan. European Journal of Cancer 32: 235-242.

60 lino Y, Yokoe T, Maemura M, Horiguchi J, Takei H, et al. (1994) Immunochemotherapies versus chemotherapy as adjuvant 
treatment after curative resection of operable breast cancer. Anticancer research 15: 2907-3911.

61 Yokoe T, lino Y, Takei H, Horiguchi J, Koibuchi Y, et al. (1996) HLA antigen as predictive index for the outcome of breast cancer patients with adjuvant immunochemotherapy with PSK. Anticancer research 17: $2815-2818$

62 Eliza WLY, Fai CK, Chung LP (2012) Efficacy of Yun Zhi (coriolus versicolor) on survival in cancer patients: Systematic review and meta-analysis. Recent Patents on Inflammation and Allergy Drug Discovery 6: 78-87.

63 Akagi J, Baba H (2008) Prognostic value of CD57+ T lymphocytes in the peripheral blood of patients with advanced gastric cancer. International journal of clinical oncology 13: 528-535.

64 Smith PK, Krohn RI, Hermanson GT, Mallia AK, Gartner FH, et al. (1985) Measurement of protein using bicinchoninic acid. Analytical biochemistry 150: 76-85.

65 Brigham A, Bryan JK, Ceurvels J, Conquer J, Costa D, et al. (2013) Cordyceps (cordyceps spp.): An evidence-based systematic review by the natural standard research collaboration. Alternative and Complementary Therapies 19: 326-336.

66 Li ZP, Cao Q, Dong ZY, Xing Q (2004) Effect of milkvetch injection on immune function of children with tetralogy of Fallot after radical operation. Zhongguo Zhong Xi Yi Jie He Za Zhi 24: 596-600.

67 Cho WCS, Leung KN (2007) In vitro and in vivo immunomodulating and immunorestorative effects of Astragalus membranaceus. Journal of Ethnopharmacology 113: 132-141.

68 Cho WCS, Leung KN (2007) In vitro and in vivo anti-tumor effects of Astragalus membranaceus. Cancer Letters 252: 43-54.

69 Caligiuri MA (2008) The biology of human natural killer-cell subsets. Sci Dire 112: 461-469.

70 Moeller MJ, Kammerer R, Von Kleist S (1998) A distinct distribution of natural killer cell subgroups in human tissues and blood. Int J Cancer 78: 533-538.

71 Ingulli E, Mondino A, Khoruts A, Jenkins MK (1997) In vivo detection of dendritic cell antigen presentation to CD4+ T cells. The Journal of Experimental Medicine 185: 2133-2141.

72 Toellner KM, Luther SA, Sze DMY, Choy RKW, Taylor DR, et al. (1998) T helper 1 (Th1) and Th2 characteristics start to develop during $T$ cell priming and are associated with an immediate ability to induce immunoglobulin class switching. J Exp Med 187: 1193-1204.

73 Bebawy M, Sze DM (2008) Targeting P-glycoprotein for effective oral anti-cancer chemotherapeutics. Curr Cancer Drug Targets 8: 47-52. 